\title{
Short-term response of phytoplankton community to over-enrichment of nutrients in a well-preserved sub-tropical estuary
}

\author{
Jose Juan Barrera-Alba ${ }^{1 *}$, Gleyci Aparecida Oliveira Moser ${ }^{2}$
}

\author{
${ }^{1}$ Departamento de Ciências do Mar, Universidade Federal de São Paulo \\ (Av. Almirante Saldanha da Gama, 89, CEP: 11030-400, Santos, SP, Brazil) \\ ${ }^{2}$ Departamento de Oceanografia Biológica, Faculdade de Oceanografia, Universidade Estadual do Rio de Janeiro \\ (Rua São Francisco Xavier, 524, CEP: 20550-900, Rio de Janeiro, RJ Brazil) \\ *Corresponding author: barrera.alba@unifesp.br
}

At the interface between marine and fresh waters represented by estuaries, chemical changes in the body of water are reflected in the biological processes. Rivers, since humans usually use them as wastewater disposal systems, also play an important role in the nutrient enrichment of coastal waters and estuaries (SMITH, 2003). The first eutrophication associated processes that is focused on in almost all studies is the excess algal growth (YOSHIYAMA; SHARP, 2006). But, as estuarine system response to nutrient enrichment has been demonstrated not to be linear, as i.e. the high-nutrient and low-growth (HNLG) conditions described by (SHARP, 2001 apud YOSHIYAMA; SHARP, 2006), other indicators of eutrophication should be considered. Moreover, it has been demonstrated that in over-enriched waters primary production is depressed due to several factors such as light limitation and toxic contaminants (YOSHIYAMA; SHARP, 2006). However, few studies have focused on the changes in phytoplankton community composition in estuarine waters as a response to nutrient enrichment (i.e. PAERL et al., 2003). Phosphorus plays an important role in the eutrophication of receiving waters, especially lakes, reservoirs, rivers and estuaries. Human activities, such as involve agricultural fertilizers and the mining of phosphate, resulting in an increased flow of this nutrient, which is efficiently retained, lead to high primary production rates which favor the appearance of algal blooms and the increased presence of aquatic weeds.

Since 2001 several research studies have been undertaken in the sub-tropical Estuarine-Lagoon System of Cananéia-Iguape, on the southeastern coast of Sao Paulo State (Brazil), with receives a huge freshwater input (average annual runoff of $435 \mathrm{~m}^{3} \mathrm{~s}^{-1}$ ) (BARRERA-ALBA et al., 2007) from an artificial channel (Valo Grande) opened in the $\mathrm{C} 19^{\text {th }}$, which causes the estuarine waters to attain dissolved inorganic phosphate levels of $\sim 3.0 \mathrm{mg}$ $\mathrm{L}^{-1}$ (BARRERA-ALBA et al., 2007). The phytoplankton response to this nutrient enrichment results in Chlorophyll a concentrations of $15.5 \mathrm{mgL}^{-1}$, abundances of $3 \times 10^{7}$ cells $\mathrm{L}^{-1}$ and primary production rates of $15.85 \mathrm{mg} \mathrm{C} \mathrm{L}^{-1} \mathrm{~h}^{-1}$ (BARRERA-ALBA et al., 2009). Also detected in this region was the presence of high densities of opportunistic species of microalgae such as Skeletonema cf. costatum and potentially toxic species of cyanobacteria (unpublished data). $S$. cf. costatum was described as an abundant species in the Cananéia region in studies produced in the $60 \mathrm{~s}$ and $70 \mathrm{~s}$, when the Valo Grande channel was open, with maximum values of $2 \times 10^{7}$ cells $\mathrm{L}^{-1}$ the Cananéia region (KUTNER; AIDAR-ARAGÃO, 1986). From 1978 to 1995 the Valo Grande channel remained closed and only 1/10 of the freshwater discharge reached the estuarine system. Under these conditions, several changes were observed in the phytoplankton community (KUTNER; AIDAR-ARAGÃO, 1986): S. costatum was almost absent in the Cananéia region during the summer; the general standing stock of phytoplankton was reduced; phytoflagellates dominated the phytoplankton community; the frequency and abundance of diatoms such as Phaeodactylum tricornutum and Lauderia annulata increased; and there was a greater abundance of dinoflagellates. It was proposed that $S$. cf. costatum should be considered an indicator of the influence of riverine waters on estuarine systems (MOSER et al., 2012). In the light of this scene, we here evaluate how phytoplankton composition responds to nutrient over-enrichment in a well-preserved sub-tropical estuary by means of controlled bioassays using the natural community of the CananéiaIguape Estuarine-Lagoon System and submitting the microalgae to different levels of eutrophication. 
The study was conducted in the northern region of the Estuarine-Lagoon System of Cananéia-Iguape, a sub-tropical estuarine system that is associated with a broad and relatively well preserved mangrove forest in Sao Paulo State, Brazil (47 55.30’ W; 25 01.14' S). This system consists of channels and four islands covering an area of approximately $10^{4}$ ha, with two main connections to the South Atlantic Ocean: Icapara Inlet at the North and Cananéia Inlet at the South. The main freshwater discharge tributary, the Valo Grande Channel (VG), is located in the northern portion with an annual mean runoff of $435 \mathrm{~m}^{3} \mathrm{~s}^{-1}$ and a particulate organic matter concentration (POM) as high as $1.0 \mathrm{~g} \mathrm{~L}^{-1}$ during the rainy season (BARRERAALBA et al., 2007). $20 \mathrm{~L}$ of estuarine water was collected from the southern region of the Cananéia-Iguape Estuarine System. The water was pre-filtered onto a $200 \mu \mathrm{m}$ nylon mesh to avoid bigger planktonic grazers. The salinity of the estuarine water was measured as 27 . Two aliquots of 400 $\mathrm{mL}$ were used for chlorophyll a analyses and two aliquots of $200 \mathrm{~mL}$ were fixed ( $0.4 \%$ formaldehyde f.c.) and stored in the dark to determinate initial phytoplankton abundance and composition. $10 \mathrm{~L}$ of estuarine water was filtered onto GF/F Whatman filters to be used as dilution water for the bioassays. Aliquots of this water were frozen-preserved to determine the natural inorganic dissolved nutrient concentrations. A F/2 medium (GUILLARD, 1975) was used to simulate different eutrophication levels. Triplicates of six treatments of nutrient concentrations were used: $2 \mathrm{~F}$, F, F/2, F/20, F/100 and F/200 (Table 1). Also, no-nutrient addition (NNA) incubation was used as control for growth under the natural nutrient level. Triplicates of the natural phytoplankton community were kept for each nutrient level and for the control in $500 \mathrm{~mL}(250 \mathrm{~mL}$ of estuarine water $+250 \mathrm{~mL}$ of dilution water) in erlenmeyer flasks for 13 days, at controlled temperature $\left(21^{\circ} \mathrm{C} \pm 1{ }^{\circ} \mathrm{C}\right)$ and in $12 \mathrm{~h}: 12 \mathrm{~h}$ light/ dark cycles. Pigment concentrations, cell abundances and taxonomic composition were measured throughout the incubation experiment. For the photosynthetic pigments analysis, aliquots of $10 \mathrm{~mL}$ of each triplicate were filtered through GF/F Whatman glass fiber filters. Chlorophyll concentrations (Chl-a) were determined according to JEFFREY and HUMPHREY (1975). For cell abundances and taxonomic composition aliquots of $10 \mathrm{~mL}$ of each triplicate were preserved with Lugol solution and the mixture of the triplicates was analyzed using an Utermöhl chamber and an inverted optical microscope under 200x and 400x magnifications (UTERMÖHL, 1958). Species richness (S) was calculated as the number of taxa identified in each sample. The species diversity index (H') was calculated following ShannonWeaver's (PIELOW, 1977) formula. The evenness (E) of the microbial communities was calculated by comparing the actual diversity to the maximum diversity (H'max).

In terms of chlorophyll a (Chl.a), only treatments F/2, $\mathrm{F}$ and $2 \mathrm{~F}$ showed an exponential growth phase after 8 days of experiment (Figure 1a). After 13 days of incubation, Chl.a values between 470 and $630 \mu \mathrm{g} \mathrm{L}^{-1}$ were observed and the F/2 treatment seemed to show a stationary phase. In terms of growth rates, these treatments showed rates between $1.5(\mathrm{~F} / 2)$ and $2.0 \mathrm{~h}^{-1}(2 \mathrm{~F})$. In the F/20 treatment an increase in Chl. $a$ was observed after 6 days, with a growth rate of $0.9 \mathrm{~h}^{-1}$ for this phase, but a decrease was registered after 8 days of experiment (Table 2). The treatments NNA, F/200 and F/100 did not show a growth trend, with growth

Table 1. Nutrient composition and concentration $\left(\mathrm{mg} \mathrm{L}^{-1}\right)$ of the different culture media used.

\begin{tabular}{|c|c|c|c|c|c|c|c|}
\hline & \multirow[b]{2}{*}{ Component } & \multicolumn{6}{|c|}{ Treatment } \\
\hline & & $\mathrm{F} / 200$ & $\mathrm{~F} / 100$ & $\mathrm{~F} / 20$ & $F / 2$ & F & $2 \mathrm{~F}$ \\
\hline \multirow{3}{*}{ Macronutrients } & Nitrogen: Nitrate & 0.75 & 1.5 & 7.5 & 75 & 150 & 300 \\
\hline & Sodium phosphate & 0.05 & 0.1 & 0.5 & 5 & 10 & 20 \\
\hline & Silica & 0.3 & 0.6 & 3 & 30 & 60 & 120 \\
\hline \multirow{6}{*}{ Micronutrients } & EDTA-Fe & 0.043 & 0.086 & 0.43 & 4.3 & 8.6 & 19.2 \\
\hline & Copper sulfate & 0.098 & 0.196 & 0.98 & 9.8 & 19.6 & 39.2 \\
\hline & Zinc sulfate & 0.220 & 0.440 & 2.2 & 22.0 & 44.0 & 88.0 \\
\hline & Cobalt chloride & 0.100 & 0.200 & 1.0 & 10.0 & 20.0 & 40.0 \\
\hline & Manganese chloride & 1.80 & 3.60 & 18.0 & 180.0 & 360.0 & 720.0 \\
\hline & Sodium molybdate & 0.63 & 1.26 & 6.3 & 63.0 & 126.0 & 252.0 \\
\hline \multirow{3}{*}{ Vitamins } & Biotin & 0.01 & 0.02 & 0.1 & 1.0 & 2.0 & 4.0 \\
\hline & Cyanocobalamin $\left(\mathrm{B}_{12}\right)$ & 0.01 & 0.02 & 0.1 & 1.0 & 2.0 & 4.0 \\
\hline & Thiamine $\mathrm{HCl}\left(\mathrm{B}_{1}\right)$ & 0.20 & 0.40 & 2.0 & 20.0 & 40.0 & 80.0 \\
\hline
\end{tabular}


rates $<0.2 \mathrm{~h}^{-1}$. Abundance results registered a similar pattern to those observed for Chl. $a$ in each treatment (Figure 1b). After 13 days of incubation, the F/2 and $F$ treatments showed a lower growth rate (abundances between 24.6 and $33.761 \times 10^{7}$ cells $\mathrm{L}^{-1}$ ), while the $2 \mathrm{~F}$ treatment still remained in an exponential phase, attaining an abundance of $61 \times 10^{7}$ cells $\mathrm{L}^{-1}$.

Over the period of the experiment 68 taxa of the phytoplankton community were identified. Bacillariophyta was the most important group in terms of number of species (63.2\%), followed by Dinophyta $(25.0 \%)$, Haptophyta (2.9\%), Chlorophyta (1.5\%), Euglenophyta (1.5\%), Ochrophyta $(1.5 \%)$ and by prokaryote Cyanobacteria (4.4\%).

In terms of cell density, the initial phytoplankton community was dominated by centric diatoms, especially by Skeletonema cf. costatum which accounted for $\sim 93 \%$ of total density (Figure 2). Over the period of the experiment, a change in taxonomic composition was observed in all the treatments. In the NNA and F/200 treatments, the contribution of centric diatoms decreased to the end of the period, when $S$. costatum represented $\sim 50 \%$ of the total, and an increase in the cyanobacteria contribution, reaching $\sim 60 \%$ of total density, was observed (Figures $2 \mathrm{a}$ and $2 b$ ). Species richness decreased along the incubation period, whereas the Shannon-Weaver diversity index increased (Table 3). Treatments F/100 and F/20 also presented a decrease in the centric diatom contribution over the incubation period (the $S$. cf. costatum contribution decreasing from $\sim 90 \%$ to $9 \%$ ), whereas an increase in the contribution of pennate diatoms (Thalassionema nitzschioides (26 - 50\%), Navicula spp (29 - 55\%) and cyanobacteria ( $25 \%$ ) occurred at the end of the incubation period (Figures 2c and 2d). Species richness increased along the period of the experiment in all treatments until day 7 , but thereafter decreased to values similar to or lower than those observed at the beginning (Table 3 ). Both diversity and evenness showed a similar trend over the period of the experiment. The contribution of centric and pennate diatoms also decreased in the $F / 2$ treatment during the period of the experiment after day 5 (or, the $5^{\text {th }}$ day) to day 10 (Figure 2e). However, at the end of the period cyanobacteria were the predominant taxonomic group $(\sim 60 \%)$. The predominance of cyanobacteria was observed in the $\mathrm{F}$ treatment and increased from day $5(\sim 48 \%)$ to the end of the experiment $(\sim 78 \%)$. The contribution of pennate diatoms was always lower than $30 \%$ along the study period (Figure $2 \mathrm{f}$ ). In treatment $2 \mathrm{~F}$, after a higher contribution of cyanobacteria between days 5 and 7 (46 - 60\%), pennate diatoms, mainly Navicula spp, were the predominant taxa at the end of the period ( 79\%) (Figure $2 \mathrm{~g}$ ). For F/2, F and $2 \mathrm{~F}$ treatments, species richness, diversity and evenness increased during the experiment, but decreased to the end of the period (Table 3 )

The phytoplankton community of the Southern region of the Cananéia-Iguape Estuarine-Lagoon System was dominated by diatoms, especially by the opportunistic chain-forming centric diatom Skeletonema cf. costatum. This species used to form blooms until 1978, when the main source of freshwater to the estuarine system was closed, and was replaced by small flagellates, dinoflagellates and non-chain-forming centric diatoms (KUTNER; AIDARARAGÃO, 1986; BRAGA, 1995). S. cf. costatum has been described as forming blooms in different coastal
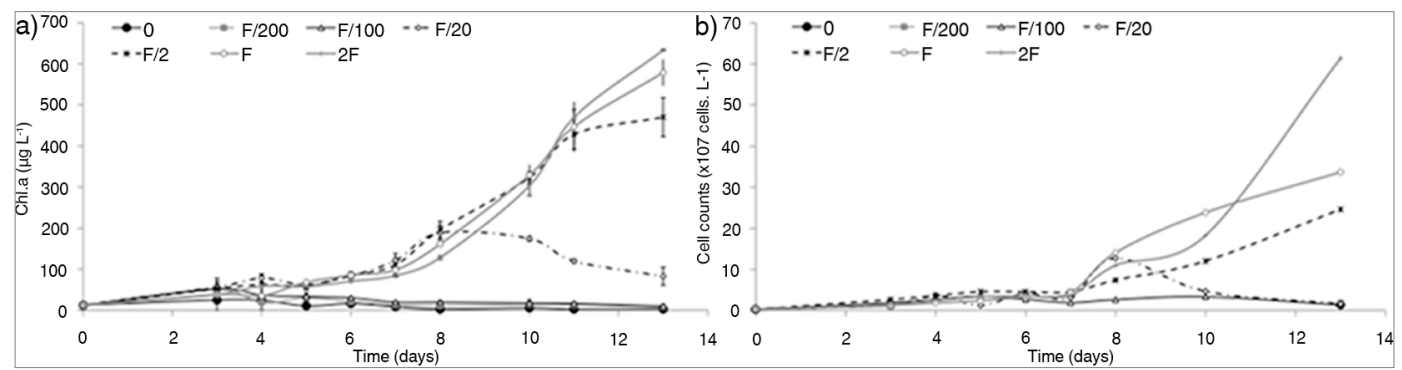

Figure 1. Variation of (a) Chlorophyll a concentration $\left(\mu \mathrm{g} \mathrm{L}^{-1}\right)$ and (b) cell counts (cells $\left.\mathrm{L}^{-1}\right)$ during the experiment for the different treatments: nonutrient addition (NNA) and different F/2 medium (Guillard, 1975) concentration (2F, F, F/2, F/20, F/100 and F/200).

Table 2. Growth rates under different treatments.

\begin{tabular}{ccccccccc}
\hline & \multicolumn{9}{c}{ Treatment } \\
\cline { 2 - 8 } & NNA & $\mathrm{F} / 200$ & $\mathrm{~F} / 100$ & $\mathrm{~F} / 20$ & $\mathrm{~F} / 2$ & $\mathrm{~F}$ & $2 \mathrm{~F}$ \\
\hline Growth rate $\left(\mathrm{h}^{-1}\right)$ & 0.12 & 0.06 & 0.12 & 0.92 & 1.47 & 1.81 & 1.99 \\
\hline
\end{tabular}



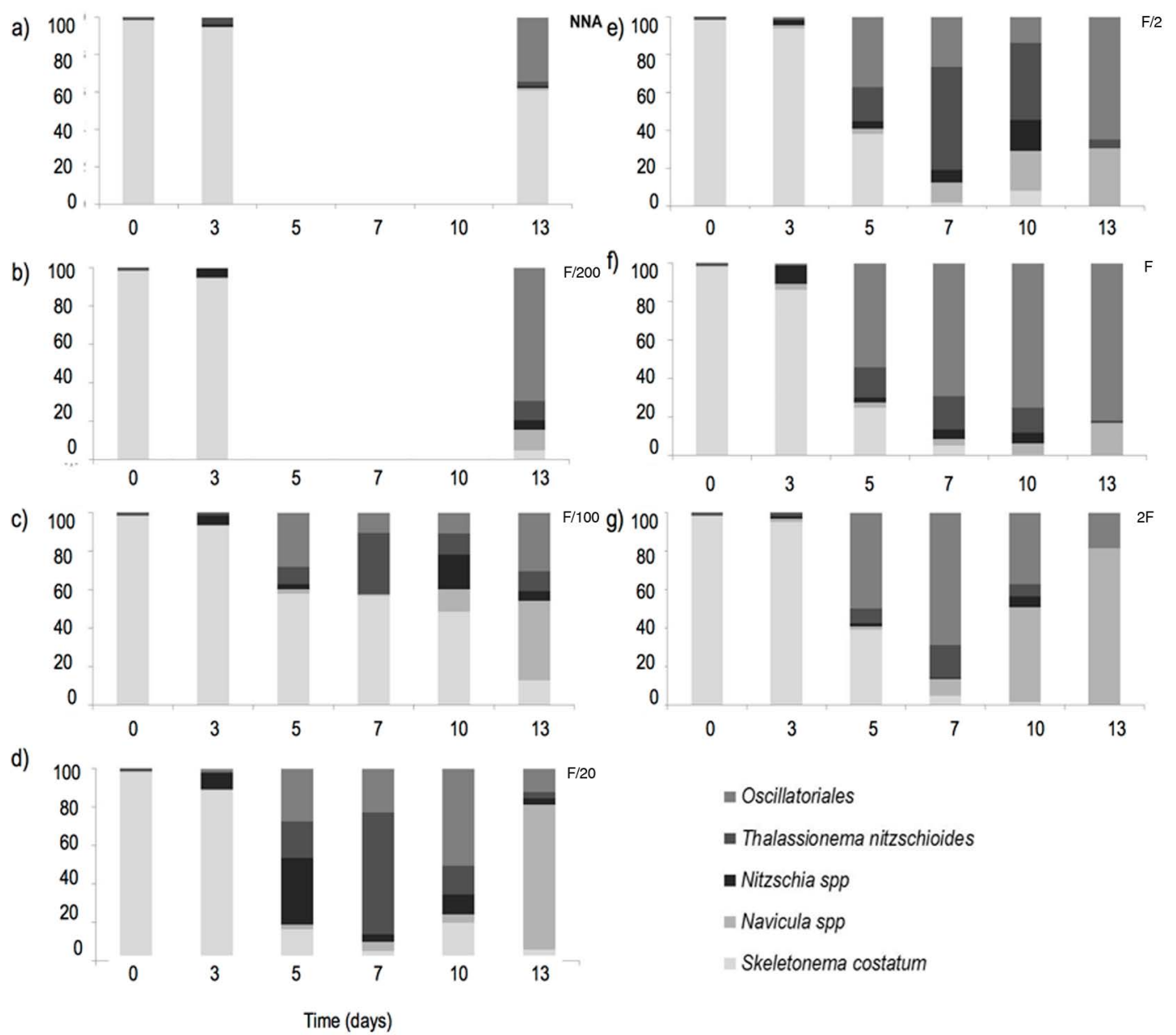

Figure 2. Variation of contribution of principal taxa identified during the experiment for the different treatments: no-nutrient addition (NNA) and different F/2 medium (Guillard, 1975) concentration (2F, F, F/2, F/20, F/100 and F/200).

Table 3. Species richness (Number of identified taxa), diversity (nats ind-1) and evenness under different treatments over the period of the experiment.

\begin{tabular}{|c|c|c|c|c|c|c|c|c|}
\hline & & \multicolumn{7}{|c|}{ Treatment } \\
\hline & & NNA & $\mathrm{F} / 200$ & $\mathrm{~F} / 100$ & $\mathrm{~F} / 20$ & $F / 2$ & $\mathrm{~F}$ & $2 \mathrm{~F}$ \\
\hline \multirow{4}{*}{ Species Richness } & $\mathrm{t}_{0}$ & 22 & 22 & 22 & 22 & 22 & 22 & 22 \\
\hline & $t_{3}$ & 16 & 29 & 26 & 26 & 23 & 21 & 18 \\
\hline & $t_{7}$ & n.d. & n.d. & 27 & 31 & 26 & 30 & 25 \\
\hline & $t_{13}$ & 18 & 20 & 21 & 24 & 20 & 16 & 17 \\
\hline \multirow{4}{*}{ Diversity } & $\mathrm{t}_{0}$ & 0.43 & 0.43 & 0.43 & 0.43 & 0.43 & 0.43 & 0.43 \\
\hline & $\mathrm{t}_{3}$ & 0.55 & 0.76 & 0.84 & 1.05 & 0.66 & 1.00 & 0.49 \\
\hline & $t_{7}$ & n.d. & n.d. & 1.83 & 1.87 & 1.94 & 1.96 & 1.79 \\
\hline & $t_{13}$ & 1.44 & 1.54 & 2.37 & 2.01 & 1.47 & 1.34 & 1.22 \\
\hline \multirow{4}{*}{ Eveness } & $\mathrm{t}_{0}$ & 0.14 & 0.14 & 0.14 & 0.14 & 0.14 & 0.14 & 0.14 \\
\hline & $\mathrm{t}_{3}$ & 0.20 & 0.22 & 0.26 & 0.32 & 0.21 & 0.33 & 0.17 \\
\hline & $\mathrm{t}_{7}$ & n.d. & n.d. & 0.56 & 0.55 & 0.60 & 0.58 & 0.56 \\
\hline & $t_{13}$ & 0.50 & 0.51 & 0.78 & 0.63 & 0.49 & 0.48 & 0.43 \\
\hline
\end{tabular}


environments associated with heavy rain, warm, lowsalinity and eutrophic water conditions (PRATT, 1966; YAMAMOTO; TSUCHIYA, 1995; CHEN et al., 1996; YAMAMOTO; HATTA, 2004; PATIL; ANIL, 2008; MELO-MAGALHÃES et al., 2009; D'COSTA; ANIL, 2010). After the re-opening of the artificial freshwater channel, the $S$. cf. costatum was again registered in high cell densities (in this present study). Previous bioassay studies of $S$. cf. costatum have shown that the Ribeira de Iguape river water enhances the growth of this species (AIDAR-ARAGÃO; MARQUES, 1986).

Even the natural waters from the Estuarine-Lagoon System of Cananéia-Iguape are rich in macronutrients; the incubation experiment showed that no nutrient addition or even the addition of low levels $(<F / 20)$ resulted in phytoplankton growth after seven days of incubation, as observed in high-nutrient treatments (F/2, F and $2 \mathrm{~F}$ ). Independent of the concentration of nutrients added, all the treatments showed a shift in taxonomic composition. So, in natural estuarine waters the predominance of long chain-forming centric diatoms (e.g. Skeletonema cf. costatum) was observed, these being substituted by motile pennate diatoms (e.g Navicula spp), chain-forming pennate diatoms (e.g. Thalassionema nitzschioides) or cyanobacteria filaments depending on the level of nutrient concentration. The predominance of Cyanobacteria at the end of the incubation experiment both at very low and relatively high nutrient levels could have different explanations. At low nutrient levels, final total cell densities were twice as low as the initial ones, but cyanobacteria densities increased by 3-4 orders of magnitude $\left(\sim 10^{6}-10^{7}\right.$ cells $\left.\mathrm{L}^{-1}\right)$. Cyanobacteria were probably mainly represented by nitrogen-fixing genera like Anabaena, which can benefit from an advantage in nutrient-limiting conditions due to their high nutrient-uptake rate, affinity, and storage capacity (AUBRIOT; BONILLA, 2012). On the other hand, at high-nutrient treatments, where the cyanobacteria reached densities of $\sim 10^{8}$ cells $\mathrm{L}^{-1}$, selective adaptation to probable nitrogen-limitation conditions could occur. High densities $\left(\sim 10^{7}-10^{8}\right.$ cells $\left.\mathrm{L}^{-1}\right)$ of motile pennate diatoms, such as Navicula spp, observed in high-nutrients treatments could be explained by the ability of benthic microalgae to adapt to high nutrient concentrations, and have higher growth rates, storage capacity and uptake than planktonic centric diatoms, such as $S$. cf. costatum (KWON et al., 2013).

In terms of diversity, both lower-nutrient (NNA and $\mathrm{F} / 200)$ and higher-nutrient $(\mathrm{F} / 2, \mathrm{~F}$ and $2 \mathrm{~F})$ concentration treatments showed lower species richness, diversity and evenness than the intermediate treatments $(\mathrm{F} / 100$ and $\mathrm{F} / 20)$. This maximal diversity in the F/100 and F/20 treatments can be explained by the promotional effects of the moderate nutrient enrichment (AGATZ et al., 1999), since few tolerant or more adaptive species would be benefited by the nutrient over-enrichment. Similar results related to microalgae community diversity have been observed in different aquatic environments (i.e. AGATZ et al., 1999; SALMASO, 2010; FONTÚRBEL; CASTAÑO-VILLA, 2011). Another factor that can reduce the phytoplankton diversity is water acidification, since diatoms can respond negatively to $\mathrm{pH}$ reduction (FONTÚRBEL; CASTAÑOVILLA, 2011).

This present study has shown that in this wellpreserved tropical estuarine system there is a quick response of phytoplankton community to different levels of eutrophication. Under high eutrophication conditions: (i) density increased more than six-fold in relation to the control after one week of incubation; (ii) there are factors potentially favorable to the formation of cyanobacteria blooms, even when they could be initially at very low cell densities, which pose a risk to the environment and local economic activities due to the potential production of cyanotoxins. Additionally, the reduction of phytoplankton diversity and changes in species composition and/or sizestructure could also have a bottom-up effect on higher trophic levels, and must be taken into consideration by decision makers in monitoring programs and in the urbanization expansion of this coastal area. This approach can also illustrate possible impacts of changes in freshwater discharge in highly urbanized estuaries.

\section{ACKNOWLEDGEMENTS}

The authors wish to express their gratitude to the Coordenação de Aperfeiçoamento de Pessoal de Nível Superior (CAPES) for the fellowship granted to J.J. Barrera-Alba.

\section{REFERENCES}

AUBRIOT, L.; BONILLA, S. Rapid regulation of phosphate uptake in freshwater cyanobacterial blooms. Aquat. Microb. Ecol., v. 67, n. 3, p. 251-263, 2012.

AIDAR ARAGÃO, E.; MARQUES, M. C. P. Testes biológicos com a água do Rio Ribeira de Iguape (São Paulo, Brasil) usando Skeletonema costatum como bio-reagente. Anais do Simpósio Internacional Algas: A Energia do Amanhã, São Paulo. Instituto Oceanográfico, Universidade de São Paulo, São Paulo, Brasil, 1986. p. 87-96. 
AGATZ, M.; ASMUS, R. M.; DEVENTER, B. Structural changes in the benthic diatom community along a eutrophication gradient on a tidal flat. Helgol. Mar. Res., v. 53, n. 2, p. 92-101, 1999.

BARRERA-ALBA, J. J.; GIANESELLA, S. M. F.; SALDANHACORREAA, F. M. P.; MOSER, G. A. O. Influence of an artificial channel in a well-preserved sub-tropical estuary. J. Coast. Res., v. 50, p. 1137-1141, 2007.

BARRERA-ALBA, J. J.; GIANESELLA, S. M. F.; MOSER, G. A. O.; SALDANHA-CORREAA, F. M. P. Influence of allochthonous organic matter on bacterioplankton biomass and activity in a eutrophic, sub-tropical estuary. Estuar. Coast. Shelf Sci., v. 82, n. 1, p. 84-94, 2009.

BRAGA, E. S. Nutrientes Dissolvidos e Produção Primária do Fitoplâncton em 2 Sistemas Costeiros do Estado de São Paulo. Tese (Doutorado) - Instituto Oceanográfico. Universidade de São Paulo. São Paulo, 1995.

CHEN, C. M.; ZHOU, C. Y.; ZHENG, A. R.; HU, H. Limitation of Environmental Factors on propagation of Skeletonema costatum. Mar. Sci. Bull., v. 15, p. 37-42, 1996.

D'COSTA, P. M.; ANIL, A. C. Diatom community dynamics in a tropical, monsoon-influenced environment: West coast of India. Cont. Shelf Res., v. 30, n. 12, p. 1324-1337, 2010.

FONTÚRBEL，F. E.; CASTAÑO-VILLA，G. J. Relationships between nutrient enrichment and the phytoplankton community at an andean oligotrophic lake: a multivariate assessment. Ecol. Apl., v. 10, n. 2, p. 75-81, 2011.

GUILLARD, R. R. L.; Culture of phytoplankton for feeding marine invertebrates. In: SMITH, W. L.; CHANLEY, M. H. (Eds.). Culture of Marine Invertebrate Animals. New York: Plenum Press, 1975. p. 26-60.

JEFFREY, S. W.; HUMPHREY, G. F. New spectrophotometric equations for determining chlorophylls a1, b1, $\mathrm{c} 1$ and $\mathrm{c} 2$ in higher plants, algae and natural phytoplankton. Biochem. Physiol. Pflanz., v. 167, p. 191-194, 1975.

KWON, H. K.; OH, S. J.; YANG, H. S. Growth and uptake kinetics of nitrate and phosphate by benthic microalgae for phytoremediation of eutrophic coastal sediments. Bioresour. Technol., v. 129, p. 387-395, 2013.

KUTNER, M. B. B.; AIDAR-ARAGÃO, E. Influência do fechamento do Valo Grande sobre a composição do fitoplâncton na região de Cananéia $\left(25^{\circ} \mathrm{S}-48^{\circ} \mathrm{W}\right)$. In: BICUDO, C. E.; TEIXERA, C.; TUNDISI, G. (Eds.). Anais do Simpósio Internacional Algas: A Energia do Amanhã, São Paulo, 1982. Instituto Oceanográfico, Universidade de São Paulo, São Paulo, Brasil, 1986. p.109-120.
MELO-MAGALHÃES, E. M.; MEDEIROS, P. R. P.; LIRA, M. C. A.; KOENING, M. L.; MOURA, A. N. Determination of eutrophic areas in Mundaú/Manguaba lagoons, AlagoasBrazil, through studies of the phytoplanktonic community. Braz. J. Biol., v. 69, n. 2, p. 271-280, 2009.

MOSER, G. A. O.; CIOTTI, A. M.; GIANNINI, M. F. C.; TONINI, R. T.; HARARI, J. Changes in phytoplankton composition in response to tides, wind-induced mixing conditions, and freshwater outflows in an urbanised estuarine complex. Braz. J. Biol., v. 72, n. 1, p. 97-111, 2012.

PAERL, H. W.; VALDES, L. M.; PINCKNEY, J. L.; PIEHLER, M. F.; DYBLE, J.; MOISANDER, P. H. Phytoplankton Photopigments as Indicators of Estuarine and Coastal Eutrophication. BioScience, v. 53, n. 10, p. 953-964, 2003.

PATIL, J. S; ANIL, A. C. Temporal variation of diatom benthic propagules in a monsoon-influenced tropical estuary. Cont. Shelf Res., v. 28, n. 17, p. 2404-2416, 2008.

PIELOU, E. C. Mathematical Ecology. New York: John Wiley \& Sons, 1977.

PRATT, D. M. Competition between Skeletonema costatum and Olishodiscus luteus in Narragansett Bay and in culture. Limnol. Oceanogr., v. 11, p. 447-455, 1966.

SALMASO, N. Long-term phytoplankton community changes in a deep subalpine lake: responses to nutrient availability and climatic fluctuations. Freshw. Biol., v. 55, n. 4, p. 825$846,2010$.

SMITH, V. H. Eutrophication of freshwater and coastal marine ecosystems a global problem. Environ. Sci. Pollut. Res., v. 10, n. 2, p. 126-139, 2003.

UTERMÖHL, H. Zur Vervollkommnung der quantitativen Phytoplankton-Methodik. Mitt. Int. Verein. Theor. Angew. Limnol., v. 9, p. 1-38, 1958.

YAMAMOTO, T.; TSUCHIYA, H. Physiological Responses of Si-Limited Skeletonema costatum to silicate Supply with Salinity Decrease. Bull. Plank. Soc., v. 42, n. 1, p. 1-17, 1995.

YAMAMOTO, T.; HATTA, G. Pulsed nutrient supply as a factor inducing phytoplankton diversity. Ecol. Modell., v. 171, n. 3, p. 247-270, 2004.

YOSHIYAMA, K.; SHARP, J. H. Phytoplankton response to nutrient enrichment in an urbanized estuary: Apparent inhibition of primary production by overeutrophication. Limnol. Oceanogr., v. 51, n. 1, p. 424-434, 2006. 